Bull. Chem. Soc. Ethiop. 2014, 28(1), 53-66.

Printed in Ethiopia

DOI: http://dx.doi.org/10.4314/bcse.v28i1.7

ISSN 1011-3924

(c) 2014 Chemical Society of Ethiopia

\title{
INFRARED SPECTRA, THERMOGRAVIMETRIC ANALYSIS AND ANTIFUNGAL STUDIES OF NOVAL Cr(III), Fe(III) AND Cu(II) 2-METHYL-QUINAZOLINONE COMPLEXES
}

\author{
S.A. Sadeek ${ }^{1 *}$, M.S. El-Attar ${ }^{1}$ and N.S. Abd El-Lattif ${ }^{2}$ \\ ${ }^{1}$ Department of Chemistry, Faculty of Science, Zagazig University, Zagazig, Egypt \\ ${ }^{2}$ Department of Pesticides Formulation, Central Agricultural Pesticides Laboratory, Cairo, \\ Egypt
}

(Received June 17, 2013; revised December 4, 2013)

\begin{abstract}
Some new solid complexes $\left[\mathrm{CrCl}_{3}(\mathrm{~L})_{3}\right] \cdot 6 \mathrm{H}_{2} \mathrm{O},\left[\mathrm{FeCl}_{3}(\mathrm{~L})_{3}\right] \cdot 6 \mathrm{H}_{2} \mathrm{O}$ and $\left[\mathrm{Cu}\left(\mathrm{CH}_{3} \mathrm{COO}\right)_{2}(\mathrm{~L})_{3}\right] \cdot 2 \mathrm{H}_{2} \mathrm{O}$ have been synthesized quantitatively by the interactions of 2-methyl-quinazolinone (L) with $\mathrm{CrCl}_{3} \cdot 6 \mathrm{H}_{2} \mathrm{O}$, $\mathrm{FeCl}_{3} \cdot 6 \mathrm{H}_{2} \mathrm{O}$ and $\mathrm{Cu}\left(\mathrm{CH}_{3} \mathrm{COO}\right)_{2} \cdot 2 \mathrm{H}_{2} \mathrm{O}$ in a mixture of an ethanol-bidistilled water $(1: 1)$, at $60{ }^{\circ} \mathrm{C}$. They were characterized by melting point, molar conductivity, magnetic moment, elemental analysis, infrared spectra and thermal analyses. The results supported the formation of the complexes and indicated that the ligand reacted as a monodentate ligand bound to the metal ion through the oxygen atom. The antifungal activity of the free ligand and their metal complexes were evaluated against several species, such as Fusarium solani, Rizoctonia solani, Sclortium rolfsii and Botryodiplodia and they showed a good antifungal activity to some selected fungal strain as compared with free ligand.
\end{abstract}

KEY WORDS: Quinazolinone; Cr(III); $\mathrm{Fe}(\mathrm{III})$; $\mathrm{Cu}(\mathrm{II})$; Antifungal activity, Thermal analyses

\section{INTRODUCTION}

2-Methyl-quinazolinone (Formula 1) is one of the important compounds from the series of quinazolinone derivatives. Quinazolinone and its derivatives are inhibitory to a number of fungal pathogens of plants, including Helminthosporium turcicum, Stagonospora nodorum, Microdochium nivale, Fusarium moniliforme, Fusarium culmorum, and Gaeumannomyces graminis. Some isolates of G. graminis, F. culmorum, F. moniliforme, F. subglutinans, and of a number of other Fusarium species are able to degrade benzoxazolinone compounds to products which are less inhibitory to fungal growth and also important compounds in chemistry and pharmacology [1-5]. They have drawn much attention due to their broad range of pharmacological properties, which include anticancer, anti-inflammatory, anticonvulsant and antidiuretic activities [6-10]. Consequently, considerable efforts have been made to explore new simple and direct approaches towards the construction of 5(4H)-quinazilinone skeletons such as via amidation of 2-aminobenzonitrile, followed by oxidative ring closure and Pd-catalyzed heterocyclyzation of nitroarenes $[11,12]$.

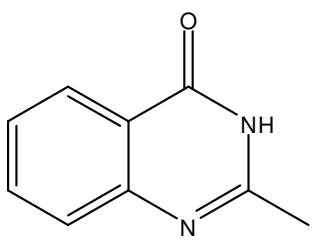

Formula 1. Structure of 2-methyl-quinazolinone.

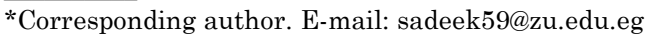


Benzoxazinone derivatives are also used as antiphlogistic drugs, antifungal and antibacterial agent $[13,14]$. If a vinyl or phosphate functional group is connected to an aromatic ring located at the position two of the heterocyclic, the resulting compounds possess antimuscular contraction properties and can be used as a hypnotic drug [15, 16]. For many years, quinazolinone derivatives and their metal complexes have been the subject of most structural and mechanical studies due to their potential biological value [17]. In recent years the chemistry of heterocyclic compounds are well known for their diverse therapeutic properties and exhibited antibacterial, anticancer, antiulcer, diuretics, anticonvulsant, antihypertensive, antitumor, antifungal, anti-AIDS and antiviral properties [18].

The present study describes the coordination behavior of novel 2-methyl-quinazolinone towards some transition elements, which may help in more understanding of the mode of chelation of them towards metals. For this purpose the complexes of $\mathrm{Cr}$ (III), $\mathrm{Fe}$ (III) and $\mathrm{Cu}$ (II) ions with 2-methyl-quinazolinone are studied in the solid state. The structure of the studied complexes is characterized using elemental analysis, infrared spectra and thermal analyses (TGA and DTG) measurements. The biological activity of the parent, 2-methyl-quinazolinone and its metal complexes has been tested against antifungal screening, Fusarium solani, Rizoctonia solani, Sclortium rolfsii and Botryodiplodia.

\section{EXPERIMENTAL}

\section{Chemicals}

All chemicals used for the synthesis of compounds were of the analytical reagent grade and of highest purity available. Cupper acetate dihydrate was purchased from Sigma, chromium chroide and ferric chloride were purchashed from Prolabo. Solvents were dried by the standard procedures [19].

\section{Instruments}

Elemental microanalysis of the solid complexes for $\mathrm{C}, \mathrm{H}, \mathrm{N}$ and halogen was carried out on a Perkin-Elmer CHN 2400 and performed at the Micro-analytical Center, Cairo University. The analysis was repeated twice to check the accuracy of the analyzed data. The percentage of the metal ions were determined gravimetrically by transforming the solid products into oxide and also determined by using atomic absorption method. Spectrometer model PYE-UNICAM SP 1900 fitted with the corresponding lamp was used for this purposed. Infrared spectra of the three solid complexes, $\left[\mathrm{CrCl}_{3}(\mathrm{~L})_{3}\right] \cdot 6 \mathrm{H}_{2} \mathrm{O}, \quad\left[\mathrm{FeCl}_{3}(\mathrm{~L})_{3}\right] \cdot 6 \mathrm{H}_{2} \mathrm{O}, \quad\left[\mathrm{Cu}\left(\mathrm{CH}_{3} \mathrm{COO}\right)_{2}(\mathrm{~L})_{3}\right] \cdot 2 \mathrm{H}_{2} \mathrm{O}$, 2methyl-quinazolinone and the final products of the thermogravimetric analysis were recorded on a Perkin-Elmer FT-IR type 1650 spectrophotometer in wave number region $4000-400 \mathrm{~cm}^{-1}$. The spectra were recorded as $\mathrm{KBr}$ pellets. The thermal analyses (TGA and DTG) were carried out in dynamic nitrogen atmosphere $\left(20 \mathrm{~mL} \cdot \mathrm{min}^{-1}\right)$ with a heating rate of $10{ }^{\circ} \mathrm{C} \mathrm{min}^{-1}$ using Shimadzu TGA-50H thermal analyzer within the temperature range from room temperature to $1200{ }^{\circ} \mathrm{C}$. Molar conductivities of the solution of the ligand and metal complexes in DMSO at $1 \times 10^{-3} \mathrm{M}$ were measured on CONSORT k410. All measurements were carried out at ambient temperature with freshly prepared solution.

Synthesis of 2-methyl-quinazolinone

The pale brown of 2-methyl-quinazolinone was prepared according to published method [20, 21] by heating of $10 \mathrm{mmol} 2$-methyl-3,1-(4H)-benzoxazin-4-one and $25 \mathrm{~mL}$ of formamide for 3 
$\mathrm{h}$ in oil bath and the reaction mixture was left aside at room temperature until the precipitation occurs, the solution was filtered under vacuum and the solid product was recrystallized from suitable solvent (ethanol).

Synthesis of metal complexes

The black solid complex $\left[\mathrm{CrCl}_{3}(\mathrm{~L})_{3}\right] \cdot 6 \mathrm{H}_{2} \mathrm{O}$ was prepared by adding $2 \mathrm{mmol}(0.533 \mathrm{~g})$ of chromium chloride $\left(\mathrm{CrCl}_{3} .6 \mathrm{H}_{2} \mathrm{O}\right)$ in $25 \mathrm{~mL}$ mixture of an ethanol-water (1:1) drop wisely to a stirred hot solution $\left(60{ }^{\circ} \mathrm{C}\right)$ of $6 \mathrm{mmol}(0.966 \mathrm{~g})$ of 2-methyl-quinazolinone in $25 \mathrm{~mL}$ of the same mixture in 1:3 molar ratio. The reaction mixture was stirred under heating for four hours where upon the complex precipitated. The black solid complex collected by filtration and purified by washing with an ethanol-water mixture and diethyl ether. The gray and light green solid complexes of $\left[\mathrm{FeCl}_{3}(\mathrm{~L})_{3}\right] \cdot 6 \mathrm{H}_{2} \mathrm{O}$ and $\left[\mathrm{Cu}\left(\mathrm{CH}_{3} \mathrm{COO}\right)_{2}(\mathrm{~L})_{3}\right] \cdot 2 \mathrm{H}_{2} \mathrm{O}$, respectivly, were prepared in a similar manner described above by using $\mathrm{FeCl}_{3} \cdot 6 \mathrm{H}_{2} \mathrm{O}$ or $\mathrm{Cu}\left(\mathrm{CH}_{3} \mathrm{COO}\right)_{2} \cdot 2 \mathrm{H}_{2} \mathrm{O}$, respectivly, in 1:3 molar ratio. The three complexes were characterized by their elemental analysis, infrared spectra as well as thermal analyses.

\section{Antifungal activity}

The effect of the prepared compound 2-methyl-quinazolinone and its metal complexes on the linear growth of tested soil fungi, such as Fusarium solani, Rizoctonia solani, Sclortium rolfsii and Botryodiplodia on potatoes dextrose agar (PDA) medium was evaluated by a previously reported modified method [22]. The medium was prepared as usual using $50 \mathrm{~mL}$ of PDA and transferred to a conical flask $(150 \mathrm{~mL})$ and autoclaved.

Adequate drops of $25 \%$ of lactic acid were added on PDA after sterilization and before pouring in Petri dishes to prevent bacterial growth. Appropriate amounts of each prepared compound were added to flasks containing PDA medium just before solidifying and shacked before pouring to obtain the required concentrations of the prepared compounds $(1000 \mu \mathrm{g} / \mathrm{mL})$. The different preparations of each compound were then poured in Petri dishes. Four dishes were used as replicates for each compound. Agar disks $6 \mathrm{~mm}$ in diameter of growth cultures of each tested fungus on PDA medium were seeded on center of each amended PDA plate with tested compounds. Other four dishes that were not treated with any chemical were incubated with fungal disks and used as control. All dishes were incubated at $25 \pm 1^{\circ} \mathrm{C}$. The linear growth of fungal mycelium was measured in $\mathrm{mm}$ when any of the colonies covered the plate. The data of linear growth of fungi as affected by prepared compounds are recorded.

\section{RESULTS AND DISCUSSION}

The prepared solid complexes were subjected to elemental analysis (C, H N, halogen and metal content), infrared spectral studies (IR), and thermal analyses (TGA and DTG), to identify their tentative formula in a trial to elucidate their molecular structures. All these complexes were colored and hydrates with a metal to ligand ratio amounting to $1: 3$ for three complexes and the metal ions complete the coordination number to six for $\mathrm{Cr}$ (III) and $\mathrm{Fe}$ (III) or five for $\mathrm{Cu}$ (II) with chloride or acetate ions, respectively. The structures of the complexes suggested from the elemental analysis agreed well with their proposed formula (Table 1). The magnetic moment of $\mathrm{Fe}$ (III) complex at room temperature was found to be at 2.42 B.M., which indicated for low spin paramagnetic $\mathrm{Fe}(\mathrm{III})$ in octahedral geometry [23, 24]. For $\mathrm{Cu}$ (II) complex the measured magnetic moment value was 1.77 B.M., which is very close to that of the spin only value (1.71 B.M.) expected for a complex having one $\mathrm{Cu}$ (II) with a single unpaired electron [25]. Also, the 
magnetic moment for $\mathrm{Cr}$ (III) complex was found at 3.82 B.M. [24]. Molar conductance values of 2-methyl-quinazolinone and all complexes were found to be in the range $8.11-12.50 \mathrm{~S} \mathrm{~cm}^{2}$ $\mathrm{mol}^{-1}$ suggesting their non-elyctrolytic nature. Qualitative reactions revealed the presence of chloride and acetate as ligand (inside the complex sphere for the three complexes). The biological activity of the ligands and their metal chelates were studied against antifungal organisms Fusarium solani, Rizoctonia solani, Sclortium rolfsii and Botryodiplodia.

Table 1. Analytical, physical and elemental analysis data for $\mathrm{L}^{*}$ and their metal complexes.

\begin{tabular}{|c|c|c|c|c|c|c|}
\hline \multirow{2}{*}{$\begin{array}{l}\text { Compounds } \\
\text { M.Wt. (M.F.) }\end{array}$} & \multirow{2}{*}{$\begin{array}{c}\text { Color } \\
\text { (yield) } \%\end{array}$} & \multirow{2}{*}{$\begin{array}{l}\text { M.p. } \\
\left({ }^{\circ} \mathrm{C}\right)\end{array}$} & \multicolumn{4}{|c|}{$\%$ found (calcd.) } \\
\hline & & & $\mathrm{C}$ & $\mathrm{H}$ & $\mathrm{N}$ & $\mathrm{M}$ \\
\hline $\begin{array}{l}\mathrm{L} \\
160\left(\mathrm{C}_{9} \mathrm{H}_{8} \mathrm{~N}_{2} \mathrm{O}\right)\end{array}$ & $\begin{array}{c}\text { Pale brown } \\
(85)\end{array}$ & 132 & $\begin{array}{c}67.5 \\
(67.5) \\
\end{array}$ & $\begin{array}{c}4.95 \\
(5.00) \\
\end{array}$ & $\begin{array}{c}17.35 \\
(17.50) \\
\end{array}$ & - \\
\hline $\begin{array}{l}\left.\mathrm{CrCl}_{3}(\mathrm{~L})_{3}\right] \cdot 6 \mathrm{H}_{2} \mathrm{O} \\
746.5\left(\mathrm{CrC}_{27} \mathrm{H}_{36} \mathrm{Cl}_{3} \mathrm{~N}_{6} \mathrm{O}_{9}\right)\end{array}$ & $\begin{array}{c}\text { Black } \\
(75)\end{array}$ & $>300$ & $\begin{array}{c}43.49 \\
(43.40) \\
\end{array}$ & $\begin{array}{c}4.84 \\
(4.82) \\
\end{array}$ & $\begin{array}{c}11.28 \\
(11.25) \\
\end{array}$ & $\begin{array}{r}6.87 \\
(6.96) \\
\end{array}$ \\
\hline $\begin{array}{l}{\left[\mathrm{FeCl}_{3}(\mathrm{~L})_{3}\right] \cdot 6 \mathrm{H}_{2} \mathrm{O}} \\
750.34\left(\mathrm{FeC}_{27} \mathrm{H}_{36} \mathrm{Cl}_{3} \mathrm{~N}_{6} \mathrm{O}_{9}\right)\end{array}$ & $\begin{array}{l}\text { Gray } \\
(71)\end{array}$ & $>300$ & $\begin{array}{c}42.99 \\
(43.17)\end{array}$ & $\begin{array}{c}4.76 \\
(4.79) \\
\end{array}$ & $\begin{array}{c}11.07 \\
(11.19)\end{array}$ & $\begin{array}{r}7.39 \\
(7.44) \\
\end{array}$ \\
\hline $\begin{array}{l}{\left[\mathrm{Cu}\left(\mathrm{CH}_{3} \mathrm{COO}\right)_{2}(\mathrm{~L})_{3}\right] \cdot 2 \mathrm{H}_{2} \mathrm{O}} \\
697.54\left(\mathrm{CuC}_{31} \mathrm{H}_{34} \mathrm{~N}_{6} \mathrm{O}_{9}\right)\end{array}$ & $\begin{array}{l}\text { Light green } \\
(75)\end{array}$ & $>300$ & $\begin{array}{c}53.29 \\
(53.33)\end{array}$ & $\begin{array}{c}4.84 \\
(4.87)\end{array}$ & $\begin{array}{c}12.00 \\
(12.04)\end{array}$ & $\begin{array}{r}8.98 \\
(9.10)\end{array}$ \\
\hline
\end{tabular}

\section{IR spectral studies}

The infrared spectra of 2-methyl-quinazolinone, $\left[\mathrm{CrCl}_{3}(\mathrm{~L})_{3}\right] \cdot 6 \mathrm{H}_{2} \mathrm{O},\left[\mathrm{FeCl}_{3}(\mathrm{~L})_{3}\right] \cdot 6 \mathrm{H}_{2} \mathrm{O}$ and $\left[\mathrm{Cu}\left(\mathrm{CH}_{3} \mathrm{COO}\right)_{2}(\mathrm{~L})_{3}\right] \cdot 2 \mathrm{H}_{2} \mathrm{O}$ are listed in Table 2. The infrared spectra of the three complexes were compared with those of the free ligands in order to determine the coordination sites that may involved in chelation. There were some guide peaks, in the spectra of the ligand, which were a good help for achieving this goal. These peaks were expected to be involved in chelation. The position and/or the intensities of these peaks were expected to be changed upon chelation. The presence of the spectral absorption bands in the region $3475-3395 \mathrm{~cm}^{-1}$ indicated the presence of water molecules in the obtained complexes [26, 27]. The characteristic $v(\mathrm{~N}-\mathrm{H})$ stretching frequencies, appeared in the region $3362-3210 \mathrm{~cm}^{-1}$. The stretching vibrations $v(\mathrm{C}-\mathrm{H})$ of phenyl groups in all complexes occurred as a number of bands in the range $3182-3000 \mathrm{~cm}^{-1}$, while that the corresponding vibrations $\mathrm{v}(\mathrm{C}-\mathrm{H})$ of $-\mathrm{CH}_{3}$ unit was observed in the range 2981$2914 \mathrm{~cm}^{-1}$. The assignments of all the $\mathrm{C}-\mathrm{H}$ stretching vibrations agreed quite well with the expected in literature [28]. The $\mathrm{v}(\mathrm{C}=\mathrm{O})$ stretching vibration of free $\mathrm{L}$ was found at $1670 \mathrm{~cm}^{-1}$. The shift of $v(\mathrm{C}=\mathrm{O})$ to a lower wave numbers in the three complexes at $1621 \mathrm{~cm}^{-1}$ for $\mathrm{Cr}(\mathrm{III})$, at $1664 \mathrm{~cm}^{-1}$ for $\mathrm{Fe}$ (III) and at $1659 \mathrm{~cm}^{-1}$ for $\mathrm{Cu}$ (II) indicated the participation of 2-methylquinazolinone in coordination and the formation of a bond between the oxygen of $\mathrm{L}$ with the central metal ions, and that nitrogen atom was not the donor atom. For $\left[\mathrm{Cu}\left(\mathrm{CH}_{3} \mathrm{COO}\right)_{2}(\mathrm{~L})_{3}\right] \cdot 2 \mathrm{H}_{2} \mathrm{O}$ complex the stretching asymmetric $\left(\mathrm{v}_{\mathrm{as}}\right)$ of carboxylate group for acetate ion found at around $1689 \mathrm{~cm}^{-1}$ and of the symmetric vibrations $\left(\mathrm{V}_{\mathrm{s}}\right)$ at $1442 \mathrm{~cm}^{-1}$ confirmed the donation of acetate as monodentate. Unidentate carboxylate complexes exhibited $\Delta v$ values at $\left.>200 \mathrm{~cm}^{-1}+\Delta v=v_{\text {as }}\left(\mathrm{COO}^{-}\right)-v_{\mathrm{s}}\left(\mathrm{COO}^{-}\right)\right]$[29].

The phenyl breathing vibration, $v(C=N)$ and $v(C=C)$ in all complexes occurred as a group of medium to very strong bands lying in the range $1601-1401 \mathrm{~cm}^{-1}$ (Table 2). The $\mathrm{CH}$ deformation motions of the $-\mathrm{CH}_{3}$ group occurred as a medium band at 1381 and $1337 \mathrm{~cm}^{-1}$ for $\mathrm{L}$ and as a weak or medium bands at 1346 and $1301 \mathrm{~cm}^{-1}$ for $\mathrm{Cr}$ (III), at $1395 \mathrm{~cm}^{-1}$ for $\mathrm{Fe}$ (III) and at 1383 $\mathrm{cm}^{-1}$ for $\mathrm{Cu}(\mathrm{II})$ complexes. The $v(\mathrm{C}-\mathrm{O}), v(\mathrm{C}-\mathrm{N})$ and $v(\mathrm{C}-\mathrm{C})$ stretching vibrations in all compounds are assigned to a large number of bands lying in the $1299-1000 \mathrm{~cm}^{-1}$ region. The $\mathrm{CH}$ 
bending vibrations of the three complexes and free ligand were assigned to the group of bands of varying intensities in the range $976-704 \mathrm{~cm}^{-1}$. The assignments of these bands agree quite well with the literature [30].

The coordination of the metal ions via oxygen of $\mathrm{L}$ is also confirmed by the $\mathrm{v}(\mathrm{M}-\mathrm{O})$ bands at 571 and $510 \mathrm{~cm}^{-1}$ for $\mathrm{Cr}(\mathrm{III}), 546$ and $525 \mathrm{~cm}^{-1}$ for $\mathrm{Fe}$ (III) and at 557 and $485 \mathrm{for} \mathrm{Cu}$ (III). Therefore, from the infrared spectra, it was concluded that the 2-methyl-quinazolinone behaved as a neutral monodentate ligand with oxygen donor site involved in the coordination sphere.

Table 2. Infrared frequencies $\left(\mathrm{cm}^{-1}\right)$ and tentative assignments, (A) 2-methyl-quinazolinone; (B) $\left[\mathrm{CrCl}_{3}(\mathrm{~L})_{3}\right] \cdot 6 \mathrm{H}_{2} \mathrm{O} ;(\mathrm{C})\left[\mathrm{FeCl}_{3}(\mathrm{~L})_{3}\right] \cdot 6 \mathrm{H}_{2} \mathrm{O}$ and (D) $\left[\mathrm{Cu}\left(\mathrm{CH}_{3} \mathrm{COO}\right)_{2}(\mathrm{~L})_{3}\right] \cdot 2 \mathrm{H}_{2} \mathrm{O}$.

\begin{tabular}{|c|c|c|c|c|}
\hline A & B & $\mathrm{C}$ & $\mathrm{D}$ & Assignments \\
\hline $3424 \mathrm{br}$ & $3468 \mathrm{wbr}$ & $3475 w$ & $3395 \mathrm{mbr}$ & $\mathrm{V}(\mathrm{OH}) ; \mathrm{H}_{2} \mathrm{O}$ \\
\hline $\begin{array}{l}3307 \mathrm{w} \\
3210 \mathrm{w}\end{array}$ & $3362 \mathrm{mbr}$ & $3308 \mathrm{br}$ & $\begin{array}{l}3281 \mathrm{w} \\
3218 \mathrm{wbr}\end{array}$ & $v(\mathrm{~N}-\mathrm{H})$ \\
\hline $\begin{array}{l}3093 \mathrm{vw} \\
3063 \mathrm{vw}\end{array}$ & $\begin{array}{l}3182 \mathrm{wbr} \\
3093 \mathrm{vw}\end{array}$ & $\begin{array}{l}3172 \mathrm{vw} \\
3078 \mathrm{vw} \\
3000 \mathrm{w}\end{array}$ & $3125 w b r$ & $\mathrm{v}(\mathrm{C}-\mathrm{H}) ; \mathrm{C}-\mathrm{H}$ aromatic \\
\hline $\begin{array}{l}2981 w, \\
2934 w\end{array}$ & $\begin{array}{l}2969 \mathrm{vw} \\
2922 \mathrm{vw}\end{array}$ & $\begin{array}{l}2875 \mathrm{w} \\
2608 \mathrm{br}\end{array}$ & & $\mathrm{v}(\mathrm{C}-\mathrm{H}) ;-\mathrm{CH}_{3}$ \\
\hline $\begin{array}{l}1670 \mathrm{~s} \\
1637 \mathrm{~s}\end{array}$ & $1621 \mathrm{~s}$ & $\begin{array}{l}1664 \mathrm{~ms} \\
1615 \mathrm{~m}\end{array}$ & $\begin{array}{l}1689 \mathrm{~s} \\
1659 \mathrm{w}\end{array}$ & $\begin{array}{l}v_{a s}\left(\mathrm{COO}^{-}\right) \text {; acetate group } \\
\mathrm{v}(\mathrm{C}=\mathrm{O})\end{array}$ \\
\hline $\begin{array}{l}1601 \mathrm{vs} \\
1560 \mathrm{~m} \\
1516 \mathrm{w} \\
1468 \mathrm{~ms} \\
1428 \mathrm{~ms}\end{array}$ & $\begin{array}{l}1582 \mathrm{~s} \\
1550 \mathrm{~m} \\
1454 \mathrm{~s} \\
1401 \mathrm{vs}\end{array}$ & $\begin{array}{l}1589 \mathrm{~ms} \\
1519 \mathrm{~s} \\
1452 \mathrm{~s}\end{array}$ & $\begin{array}{l}1594 \mathrm{~s} \\
1522 \mathrm{~s} \\
1442 \mathrm{~s}\end{array}$ & $\begin{array}{l}\mathrm{v}(\mathrm{C}=\mathrm{N}) \\
\mathrm{v}(\mathrm{C}=\mathrm{C}) \text { and } \\
\text { phenyl breathing modes }\end{array}$ \\
\hline $\begin{array}{c}1381 \mathrm{~ms} \\
1337 \mathrm{~m} \\
\end{array}$ & $\begin{array}{l}1346 \mathrm{w} \\
1301 \mathrm{~m} \\
\end{array}$ & $1395 \mathrm{vs}$ & $1383 \mathrm{vs}$ & $\delta(\mathrm{C}-\mathrm{H}),-\mathrm{CH}_{3}$ \\
\hline $\begin{array}{c}1246 \mathrm{~m} \\
1182 \mathrm{~m} \\
1108 \mathrm{~m} \\
1074 \mathrm{~ms} \\
1011 \mathrm{~m}\end{array}$ & $\begin{array}{c}1257 \mathrm{~s} \\
1172 \mathrm{sh} \\
1161 \mathrm{~s} \\
1031 \mathrm{~m}\end{array}$ & $\begin{array}{l}1295 \mathrm{~s} \\
1252 \mathrm{~s} \\
1161 \mathrm{~s} \\
1062 \mathrm{vw} \\
1047 \mathrm{vw} \\
1041 \mathrm{~ms} \\
1000 \mathrm{w}\end{array}$ & $\begin{array}{l}1299 \mathrm{vs} \\
1254 \mathrm{~s} \\
1187 \mathrm{vw} \\
1153 \mathrm{~ms} \\
1112 \mathrm{w} \\
1087 \mathrm{w} \\
1041 \mathrm{~ms} \\
1014 \mathrm{w} \\
\end{array}$ & $\begin{array}{l}v(\mathrm{C}-\mathrm{O}), \\
\mathrm{v}(\mathrm{C}-\mathrm{N}) \text { and } \\
\mathrm{v}(\mathrm{C}-\mathrm{C})\end{array}$ \\
\hline $\begin{array}{l}976 w \\
924 w \\
878 m \\
828 w \\
797 w \\
773 m \\
729 w\end{array}$ & $\begin{array}{c}961 \mathrm{w} \\
904 \mathrm{vw} \\
855 \mathrm{~m} \\
804 \mathrm{~m} \\
756 \mathrm{vs} \\
707 \mathrm{~m}\end{array}$ & $\begin{array}{l}966 \mathrm{~s} \\
880 \mathrm{w} \\
854 \mathrm{w} \\
828 \mathrm{w} \\
810 \mathrm{vw} \\
790 \mathrm{vw} \\
757 \mathrm{vs} \\
704 \mathrm{~m} \\
\end{array}$ & $\begin{array}{l}966 \mathrm{~s} \\
879 \mathrm{~m} \\
851 \mathrm{~m} \\
817 \mathrm{~ms} \\
756 \mathrm{vs}\end{array}$ & $-\mathrm{CH}$ bend; phenyl $+\delta\left(\mathrm{COO}^{-}\right)$ \\
\hline $\begin{array}{c}693 \mathrm{~m} \\
604 \mathrm{vw} \\
577 \mathrm{vw} \\
520 \mathrm{vw} \\
473 \mathrm{w} \\
420 \mathrm{w} \\
\end{array}$ & $\begin{array}{l}663 \mathrm{vs} \\
571 \mathrm{~s} \\
510 \mathrm{~s} \\
435 \mathrm{~ms}\end{array}$ & $\begin{array}{l}651 \mathrm{~m} \\
623 \mathrm{~m} \\
546 \mathrm{~m} \\
525 \mathrm{w} \\
484 \mathrm{~s} \\
426 \mathrm{~m} \\
\end{array}$ & $\begin{array}{l}699 \mathrm{~s} \\
665 \mathrm{~m} \\
600 \mathrm{w} \\
557 \mathrm{w} \\
529 \mathrm{~m} \\
485 \mathrm{~m} \\
\end{array}$ & $\mathrm{v}(\mathrm{M}-\mathrm{O})+$ ring deformation \\
\hline
\end{tabular}

Key: $\mathrm{s}=$ strong, $\mathrm{m}=$ medium, $\mathrm{br}=$ broad, $\mathrm{w}=$ weak, $\mathrm{v}=$ stretching. 


\section{${ }^{1} H$ NMR spectrum}

The new ligand 2-methyl-quinazolinone was characterized using ${ }^{1} \mathrm{H}$ NMR spectrum. The ${ }^{1} \mathrm{H}$ NMR spectrum of 2-methyl-quinazolinone $\mathrm{L}$, was carried out in DMSO- $\mathrm{d}_{6}$ as a solvent. The ${ }^{1} \mathrm{H}$ NMR spectrum exhibit peaks in the range 7.4-7.9 ppm, which were assigned to $-\mathrm{CH}$ of benzene ring and the $\mathrm{NH}$ amide found at $8.00 \mathrm{ppm}$. Also, the methyl group observed at $0.9 \mathrm{ppm}$.

\section{Thermal analyses}

Thermogravimetric (TGA) and deferential thermogravimetric (DTG) were carried out for the ligand 2-methyl-quinazolinone and the three solid complexes $\left[\mathrm{CrCl}_{3}(\mathrm{~L})_{3}\right] \cdot 6 \mathrm{H}_{2} \mathrm{O}$, $\left[\mathrm{FeCl}_{3}(\mathrm{~L})_{3}\right] \cdot 6 \mathrm{H}_{2} \mathrm{O}$ and $\left[\mathrm{Cu}\left(\mathrm{CH}_{3} \mathrm{COO}\right)_{2}(\mathrm{~L})_{3}\right] \cdot 2 \mathrm{H}_{2} \mathrm{O}$ under $\mathrm{N}_{2}$ flow and heating rates were suitably controlled at $10^{\circ} \mathrm{C} \mathrm{min}^{-1}$ and the weight loss was measured from the ambient temperature up to $\sim 1200{ }^{\circ} \mathrm{C}$. The TGA and DTG curves of the complexes were shown in Figure 1. Table 3 gives the maximum temperature values $\mathrm{T}_{\max } /{ }^{\circ} \mathrm{C}$, species lost together with the corresponding weight loss for each step of the decomposition reaction. The data obtained strongly supported the proposed formulas of the ligand and the three complexes and indicate that the decomposition mode of the ligand occurred in one step at two maxima 119 and $209{ }^{\circ} \mathrm{C}$. This step was associated with a weight loss value of $100 \%$ in a good agreement with the obtained value $99.33 \%$. Thermogravimetric (TGA) curve for $\left[\mathrm{CrCl}_{3}(\mathrm{~L})_{3}\right] \cdot 6 \mathrm{H}_{2} \mathrm{O}$ showed two weight loss events. The first step of decomposition occurred in the range $40-120{ }^{\circ} \mathrm{C}$, with a maximum temperature at $72{ }^{\circ} \mathrm{C}$ corresponds to the loss of three water molecules of hydration. The second step of decomposition occurred in the range $120-1200{ }^{\circ} \mathrm{C}$, with two maxima at 230 and $376^{\circ} \mathrm{C}$. The thermal decomposition of $\left[\mathrm{Fe}(\mathrm{L})_{3} \mathrm{CL}_{3}\right] \cdot 6 \mathrm{H}_{2} \mathrm{O}$ complex proceeds two degradation steps. The first step of decomposition occurred in the range $30-200{ }^{\circ} \mathrm{C}$, with a maximum temperature at $169{ }^{\circ} \mathrm{C}$ corresponds to the loss of five water molecules. The second step of decomposition occurred in the range $200-1200{ }^{\circ} \mathrm{C}$, with four maxima at $268,321,747$ and $932{ }^{\circ} \mathrm{C}$ and was simultaneously decomposed to oxide with intermediate formation of very unstable products which were not identified [31] and is accompanied by a weight loss of $59.24 \%$, corresponding to the loss $2 \mathrm{CO}+7 \mathrm{C}_{2} \mathrm{H}_{2}+2 \mathrm{~N}_{2}+0.5 \mathrm{H}_{2} \mathrm{O}+\mathrm{H}_{2}+\mathrm{HCl}+2 \mathrm{NH}_{4} \mathrm{Cl}$. The actual weight loss from these two steps was $71.19 \%$, close to the calculated value $71.75 \%$. The TGA curve of $\left[\mathrm{Cu}\left(\mathrm{CH}_{3} \mathrm{COO}\right)_{2}(\mathrm{~L})_{3}\right] \cdot 2 \mathrm{H}_{2} \mathrm{O}$ complex (Figure 2) and the data were listed in Table 3 exhibits two main degradation steps. The first step of decomposition occurred at maximum temperature of $71{ }^{\circ} \mathrm{C}$ and was accompanied by a weight loss of $13.35 \%$, corresponding to the loss of $2 \mathrm{H}_{2} \mathrm{O}+2 \mathrm{CO}+1.5 \mathrm{H}_{2}$. The second step of decomposition occurred at one maximum $256{ }^{\circ} \mathrm{C}$ and is accompanied by a weight loss of $65.82 \%$, corresponding to the loss of $12 \mathrm{C}_{2} \mathrm{H}_{2}+4 \mathrm{NO}+\mathrm{NH}_{3}+0.5 \mathrm{~N}_{2}$ giving $\mathrm{CuO}$ as a final product. Water of crystallization lost for the three complexes at a relatively low temperature may be indicated to a weak $\mathrm{H}$-bonding involving the $\mathrm{H}_{2} \mathrm{O}$ molecule and the comnlexes.

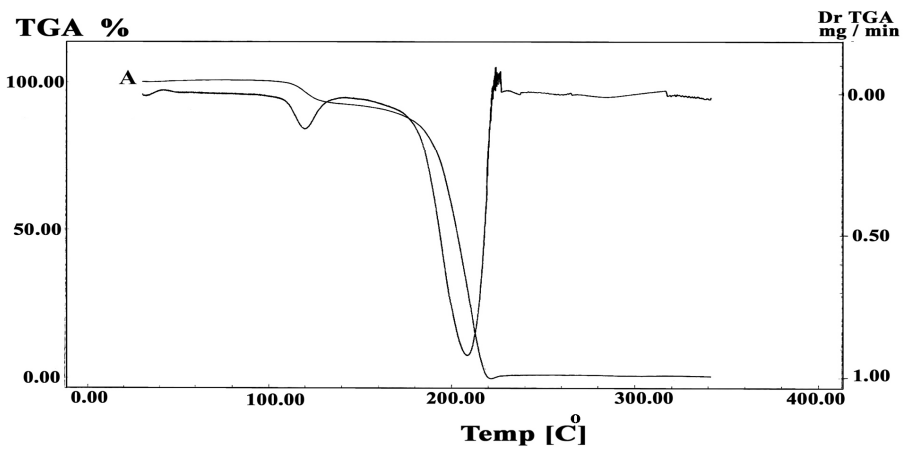

Bull. Chem. Soc. Ethiop. 2014, 28(1) 

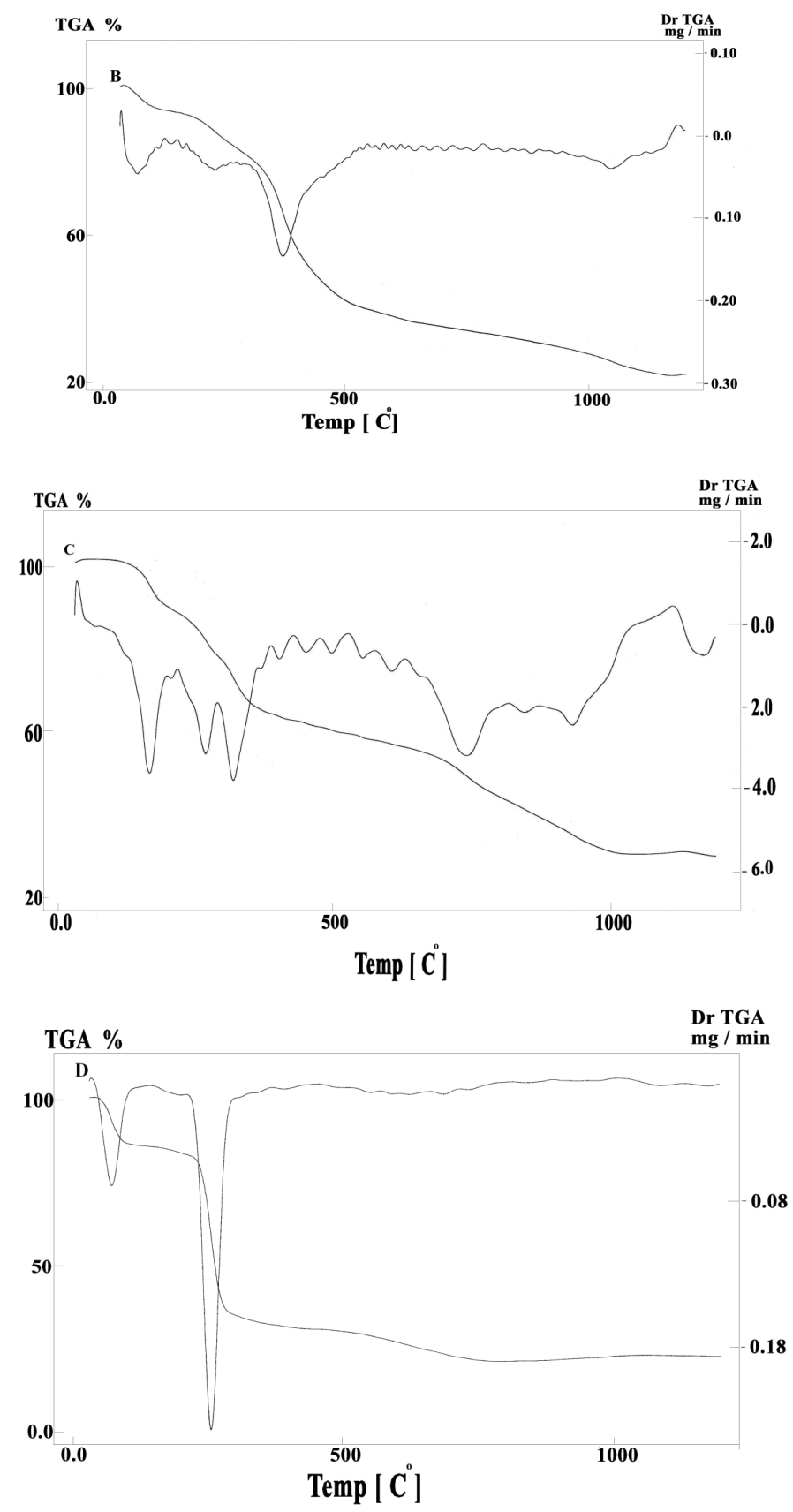

Figure 1. TGA and DTG diagram of (A) 2-methyl-quinazolinone (L), (B) $\left[\mathrm{CrCl}_{3}(\mathrm{~L})_{3}\right] \cdot 6 \mathrm{H}_{2} \mathrm{O},(\mathrm{C})$ $\left[\mathrm{FeCl}_{3}(\mathrm{~L})_{3}\right] \cdot 6 \mathrm{H}_{2} \mathrm{O}$ and (D) $\left[\mathrm{Cu}\left(\mathrm{CH}_{3} \mathrm{COO}\right)_{2}(\mathrm{~L})_{3}\right] \cdot 2 \mathrm{H}_{2} \mathrm{O}$. 
Table 3. Thermo-analytical results (TGA and DTG) of 2-methyl-quinazolinone and its metal complexes compounds.

\begin{tabular}{|c|c|c|c|c|}
\hline Compound & $\begin{array}{l}\text { TG range } \\
\left({ }^{\circ} \mathrm{C}\right)\end{array}$ & $\begin{array}{l}\text { DTG }_{\max } \\
\left({ }^{\circ} \mathrm{C}\right)\end{array}$ & $\begin{array}{l}\text { Mass loss Total mass loss } \\
\text { Found. (calcd ) \% }\end{array}$ & Assignment \\
\hline $\begin{array}{l}\text { 2-methyl- } \\
\text { quinazolinone }\end{array}$ & $40-120$ & 119,209 & $99.33(100)$ & $4 \mathrm{C}_{2} \mathrm{H}_{2}+\mathrm{CO}+\mathrm{N}_{2}$ \\
\hline$\left[\mathrm{CrCl}_{3}(\mathrm{~L})_{3}\right] \cdot 6 \mathrm{H}_{2} \mathrm{O}$ & \begin{tabular}{|l|}
$25-120$ \\
$120-1200$
\end{tabular} & $\begin{array}{l}72 \\
230 \\
376 \\
\end{array}$ & \begin{tabular}{|l|}
$7.4(7.23)$ \\
$71.09(71.34)$ \\
$78.49(78.57)$ \\
\end{tabular} & $\begin{array}{l}3 \mathrm{H}_{2} \mathrm{O} \\
0.5 \mathrm{H}_{2} \mathrm{O}+10 \mathrm{C}_{2} \mathrm{H}_{2}+ \\
\mathrm{HCl}+2 \mathrm{NH}_{4} \mathrm{Cl}+4 \mathrm{NO} \\
\end{array}$ \\
\hline$\left[\mathrm{FeCl}_{3}(\mathrm{~L})_{3}\right] \cdot 6 \mathrm{H}_{2} \mathrm{O}$ & $\begin{array}{l}30-200 \\
200-1200\end{array}$ & \begin{tabular}{|l|}
69 \\
268,320 \\
747,932 \\
\end{tabular} & $\begin{array}{l}11.95(11.99) \\
59.24(59.76) \\
\end{array}$ & $\begin{array}{l}5 \mathrm{H}_{2} \mathrm{O} \\
2 \mathrm{CO}+7 \mathrm{C}_{2} \mathrm{H}_{2}+2 \mathrm{~N}_{2}+ \\
0.5 \mathrm{H}_{2} \mathrm{O}+\mathrm{HCl}+2 \mathrm{NH}_{4} \mathrm{Cl}+\mathrm{H}_{2}\end{array}$ \\
\hline $\begin{array}{l}{\left[\mathrm{Cu}\left(\mathrm{CH}_{3} \mathrm{COO}\right)_{2}(\mathrm{~L})_{3}\right] \cdot} \\
2 \mathrm{H}_{2} \mathrm{O}\end{array}$ & $\begin{array}{l}30-140 \\
140-1000\end{array}$ & \begin{tabular}{|l|l}
71 \\
257
\end{tabular} & $\begin{array}{l}13.35(14.62) \\
65.82(66.37)\end{array}$ & $\begin{array}{l}2 \mathrm{H}_{2} \mathrm{O}+2 \mathrm{CO}+1.5 \mathrm{H}_{2} \\
12 \mathrm{C}_{2} \mathrm{H}_{2}+4 \mathrm{NO}+\mathrm{NH}_{3}+0.5 \mathrm{~N}_{2}\end{array}$ \\
\hline
\end{tabular}

According to the above discussion, the mechanisms for the thermal decomposition of the ligand and the three complexes are as follows:
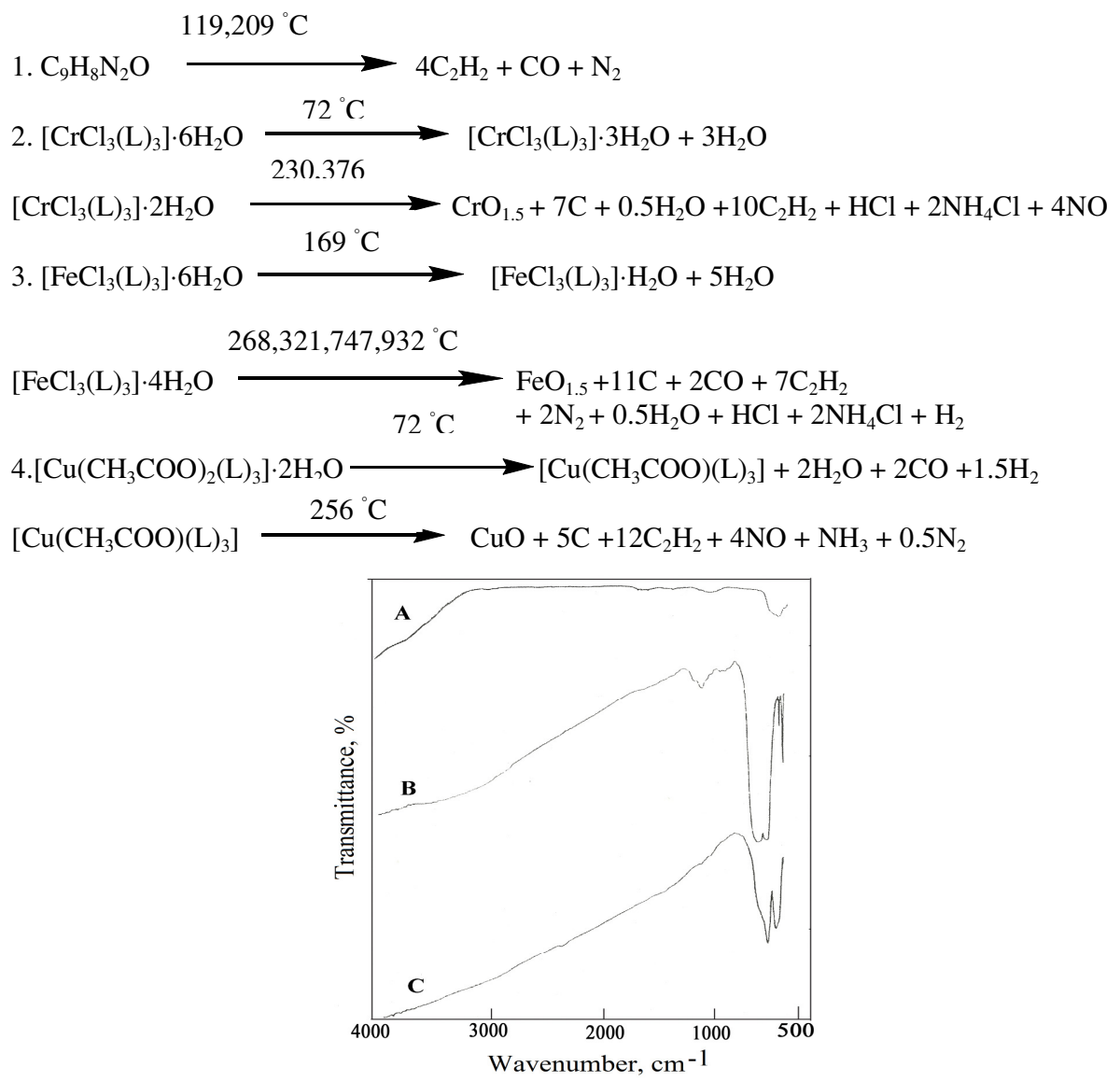

Figure 2. The final decomposition of (A) $\left[\mathrm{Cu}\left(\mathrm{CH}_{3} \mathrm{COO}\right)_{2}(\mathrm{~L})\right] \cdot 2 \mathrm{H}_{2} \mathrm{O}$, (B) $\left[\mathrm{CrCl}_{3}(\mathrm{~L})\right] \cdot 6 \mathrm{H}_{2} \mathrm{O}$ and (C) $\left[\mathrm{FeCl}_{3}(\mathrm{~L})\right] \cdot 6 \mathrm{H}_{2} \mathrm{O}$. 
The decomposition mechanisms were only based on speculation hypothesis and the thermal analysis weren't connected with a complementary technique (gas chromatography) [31]. The suggested residues confirmed only on the basis weight loss percent calculation and the infrared spectra, which clearly shows the bands associated to the metal oxides and disappearance of the bands characteristic for the 2-methyl-quinazolinone and acetate ions Figure 2.
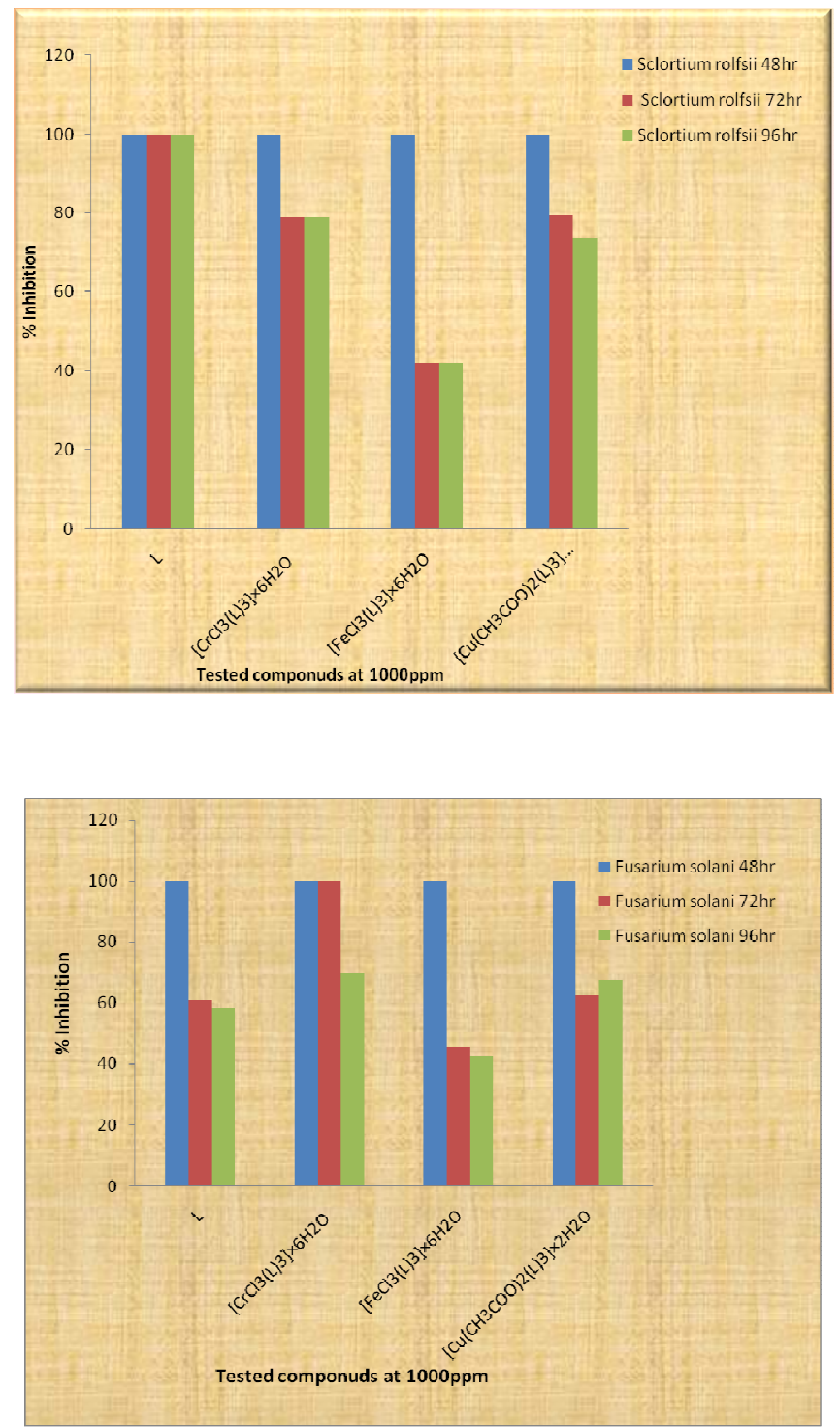

Bull. Chem. Soc. Ethiop. 2014, 28(1) 

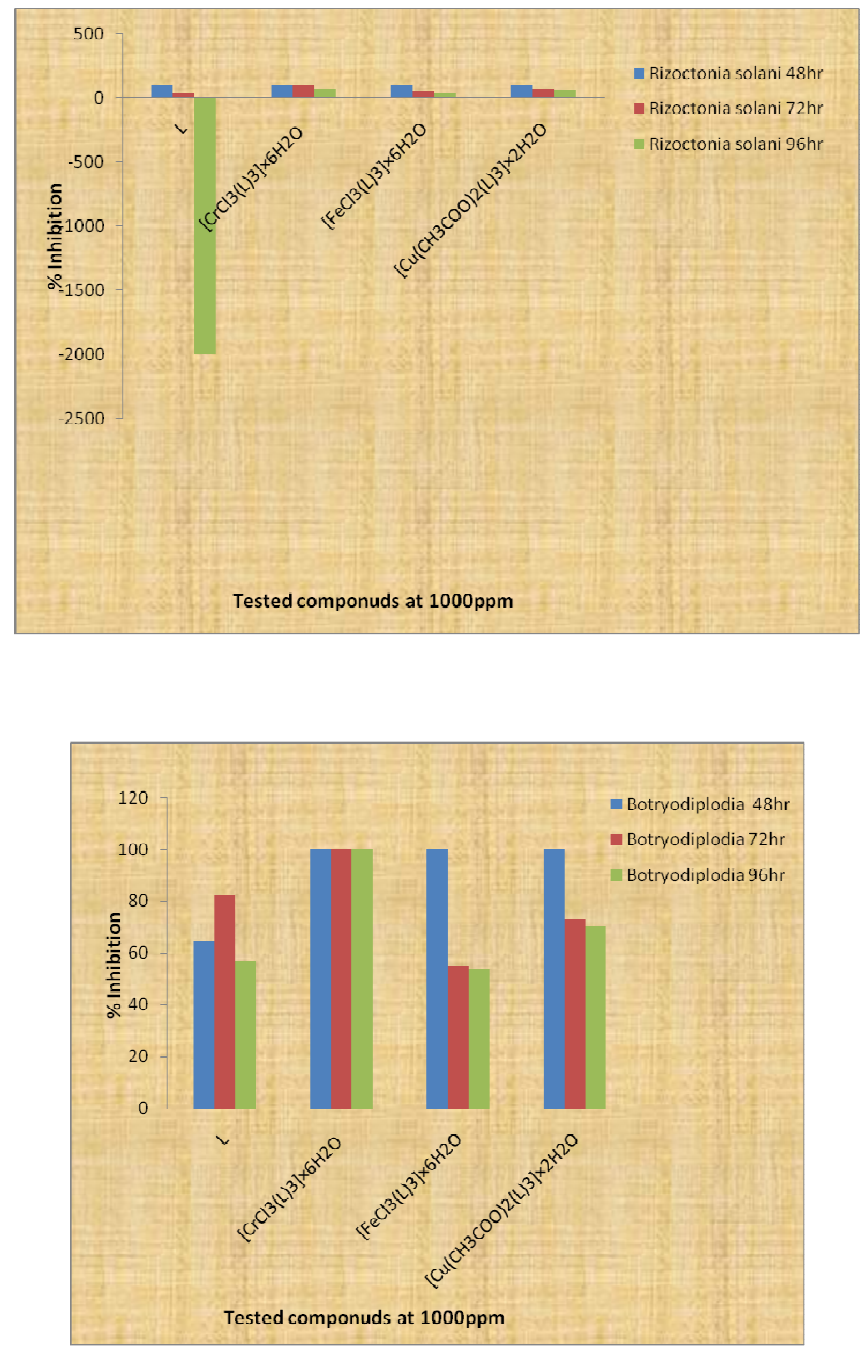

Figure 3. Statistical representation for antifungal activity of 2-methyl-quinazolinone and its complexes

The proposed structure formula (II) on the basis of the results discussed in this paper may be as follows: 

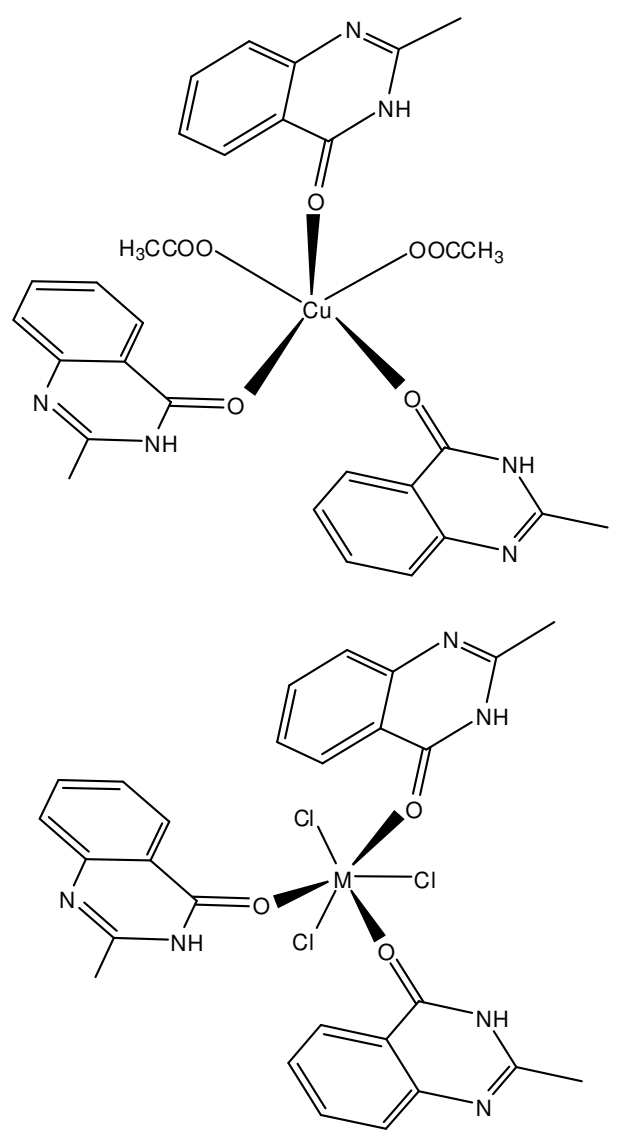

$\mathrm{M}=\mathrm{Cr}(\mathrm{III})$ or $\mathrm{Fe}(\mathrm{III})$

Formula II. The coordination mode of $\mathrm{Cu}$ (II), $\mathrm{Cr}$ (III) and $\mathrm{Fe}$ (III) with 2-methyl-quinazolinone.

Biological activities

The fungicidal activity of 2-methyl-quinazolinone and the three prepared heterocyclic complexes were evaluated under laboratory conditions. The tested fungi were Fusarium solani, Rhizoctonia solani, sclerotium rolfsii and Botryodiplodia sp. Data presented in Table 4 reveals the antifungal potency of these compounds. The highest antifungal activity for the tested compounds was observed after $48 \mathrm{~h}$ of treatment, with obvious decreasing on their activities with prolongation of incubation time at $72 \mathrm{~h}$ or $96 \mathrm{~h}$. However, the $\mathrm{Cr}(\mathrm{III})$ complex against the three fungi Fusarium solani, Rhizoctonia solani and Botryodiplodia gave the highest inhibition at 48 and $72 \mathrm{~h}$ and then the rate of inhibition was decreased to $96 \mathrm{~h}$ except for Botryodiplodia. Also, the 2-methyl-quinazolinone (L), completely inhibited the growth of Sclerotium rolfsii at the three tested incubation times. 
Table 4. Evaluation of fungicidal activity of 2-methyl -quinazolinone (L) and its complexes against different soil fungi under laboratory conditions.

\begin{tabular}{|c|c|c|c|c|}
\hline \multirow[t]{2}{*}{ Test fungi } & \multirow[t]{2}{*}{ Tested compounds at $1000 \mu \mathrm{g} / \mathrm{mL}$} & \multicolumn{3}{|c|}{$\%$ Inhibition } \\
\hline & & 48 & 72 & 96 \\
\hline \multirow[t]{4}{*}{ Sclerotium } & $\mathrm{L}$ & 100.0 & 100.0 & 100.0 \\
\hline & {$\left[\mathrm{CrCl}_{3}(\mathrm{~L})_{3}\right] \cdot 6 \mathrm{H}_{2} \mathrm{O}$} & 100.0 & 79.10 & 78.90 \\
\hline & {$\left[\mathrm{FeCl}_{3}(\mathrm{~L})_{3}\right] \cdot 6 \mathrm{H}_{2} \mathrm{O}$} & 100.0 & 42.00 & 42.00 \\
\hline & {$\left[\mathrm{Cu}\left(\mathrm{CH}_{3} \mathrm{COO}\right)_{2}\left(\mathrm{~L}_{3}\right)_{3}\right] \cdot 2 \mathrm{H}_{2} \mathrm{O}$} & 100.0 & 79.50 & 73.70 \\
\hline \multirow[t]{4}{*}{ Fusarium } & $\mathrm{L}$ & 100.0 & 60.80 & 58.40 \\
\hline & {$\left[\mathrm{CrCl}_{3}(\mathrm{~L})_{3}\right] \cdot 6 \mathrm{H}_{2} \mathrm{O}$} & 100.0 & 100.0 & 69.90 \\
\hline & {$\left[\mathrm{FeCl}_{3}(\mathrm{~L})_{3}\right] \cdot 6 \mathrm{H}_{2} \mathrm{O}$} & 100.0 & 45.50 & 42.40 \\
\hline & {$\left[\mathrm{Cu}\left(\mathrm{CH}_{3} \mathrm{COO}\right)_{2}(\mathrm{~L})_{3}\right] \cdot 2 \mathrm{H}_{2} \mathrm{O}$} & 100.0 & 62.50 & 67.50 \\
\hline \multirow[t]{4}{*}{ Rhizoctonia } & $\mathrm{L}$ & 100.0 & 47.50 & -2000 \\
\hline & {$\left[\mathrm{CrCl}_{3}(\mathrm{~L})_{3}\right] \cdot 6 \mathrm{H}_{2} \mathrm{O}$} & 100.0 & 100.0 & 76.10 \\
\hline & {$\left[\mathrm{FeCl}_{3}(\mathrm{~L})_{3}\right] \cdot 6 \mathrm{H}_{2} \mathrm{O}$} & 100.0 & 49.70 & 41.11 \\
\hline & {$\left[\mathrm{Cu}\left(\mathrm{CH}_{3} \mathrm{COO}\right)_{2}(\mathrm{~L})_{3}\right] \cdot 2 \mathrm{H}_{2} \mathrm{O}$} & 100.0 & 72.20 & 56.00 \\
\hline \multirow[t]{4}{*}{ Botryodiplodia } & $\mathrm{L}$ & 64.50 & 82.20 & 56.70 \\
\hline & {$\left[\mathrm{CrCl}_{3}(\mathrm{~L})_{3}\right] \cdot 6 \mathrm{H}_{2} \mathrm{O}$} & 100.0 & 100.0 & 100.0 \\
\hline & {$\left[\mathrm{FeCl}_{3}(\mathrm{~L})_{3}\right] \cdot 6 \mathrm{H}_{2} \mathrm{O}$} & 100.0 & 55.00 & 53.30 \\
\hline & {$\left[\mathrm{Cu}\left(\mathrm{CH}_{3} \mathrm{COO}\right)_{2}(\mathrm{~L})_{3}\right] \cdot 2 \mathrm{H}_{2} \mathrm{O}$} & 100.0 & 73.20 & 70.00 \\
\hline
\end{tabular}

Friebe et al. [3] found that, benzoxazinones and benzoxaolinones have a strong inhibition to various phytopathognic fungi including Helminthosporium turcicum, Stagonospra nodorum, Microdochium nivale and Fusarium sp. Some isolates of Fusarium sp. are able to transforme benzoxazinone compounds to less inhibitory derivative. Also Niemeyer [32] indicates that the benzoxazinone and aglycones that found as natural compound in plants and their degradation products exhibit fungistatic and bacterostatic activity. Depending on the percent of inhibition at $96 \mathrm{~h}$ quinazolinone as a most active compound against sclerotium $\mathrm{sp}$, where as $\mathrm{Cl}$ methylbenzoxazinone only was the most active compound against Fusarium solani, Rhizoctonia sp and Botryodiplodia sp. So, 2-methyl-quinazolinone is considered as qundidint compound and was used as ligand to prepare complexes. On contrary, Fusarium sp. was more sensitive to complexes $\left[\mathrm{CrCl}_{3}(\mathrm{~L})_{3}\right] \cdot 6 \mathrm{H}_{2} \mathrm{O}$ and $\left[\mathrm{Cu}\left(\mathrm{CH}_{3} \mathrm{COO}\right)_{2}(\mathrm{~L})_{3}\right] \cdot 2 \mathrm{H}_{2} \mathrm{O}$ than ligand itself (2-methylquinazolinone). On the other hand, all complexes $\left[\mathrm{CrCl}_{3}(\mathrm{~L})_{3}\right] \cdot 6 \mathrm{H}_{2} \mathrm{O},\left[\mathrm{FeCl}_{3}(\mathrm{~L})_{3}\right] \cdot 6 \mathrm{H}_{2} \mathrm{O}$ and $\left[\mathrm{Cu}\left(\mathrm{CH}_{3} \mathrm{COO}\right)_{2}(\mathrm{~L})_{3}\right] \cdot 2 \mathrm{H}_{2} \mathrm{O}$ showed fungal activity more than quinazolinone in case of Rhizoctonia sp. Also the same indication was found with complexes $\left[\mathrm{CrCl}_{3}\left(\mathrm{~L}_{3}\right] \cdot 6 \mathrm{H}_{2} \mathrm{O}\right.$ and $\left[\mathrm{Cu}\left(\mathrm{CH}_{3} \mathrm{COO}\right)_{2}(\mathrm{~L})_{3}\right] \cdot 2 \mathrm{H}_{2} \mathrm{O}$ against Botryodiplodia sp. From the above results, it could be concluded that the conjugation of metallic compounds with heterocyclic compounds in complexes changed the bioactivity of heterocyclic compounds against fungi in two forms: (i) no change in bioactivity and (ii) decrease the bioactivity less than ligand, or increase the bioactivity more than ligand these changes depending on sensitivity of tested fungi and type of metallic compounds that used in complex reaction

The physico-chemical properties of the tested active ingredient (complexes)

All complexes were insoluble in water and xylene where as $\left[\mathrm{FeCl}_{3}(\mathrm{~L})_{3}\right] \cdot 6 \mathrm{H}_{2} \mathrm{O}$ complex showed a low solubility in acetone their solubility percentages was $14 \%$. On the other hand the free acidity of all tested complexes were found in two forms (Table 5). (a) Moderate free acidity (4.60) found for $\left[\mathrm{FeCl}_{3}(\mathrm{~L})_{3}\right] \cdot 6 \mathrm{H}_{2} \mathrm{O}$ complex. (b) The two complexes $\left[\mathrm{CrCl}_{3}(\mathrm{~L})_{3}\right] \cdot 6 \mathrm{H}_{2} \mathrm{O}$ and $\left[\mathrm{Cu}\left(\mathrm{CH}_{3} \mathrm{COO}\right)_{2}(\mathrm{~L})_{3}\right] \cdot 2 \mathrm{H}_{2} \mathrm{O}$ their free acidity are 7.25 . From above results it could be concluded 
that dustable powder formulation is the suitable formulation to these active ingredient because their physico properties are not soluble in water and xylene also it will be use in controlling the soil borne fungi.

Table 5. Physico-chemical properties of diluents.

\begin{tabular}{|l|c|c|c|c|c|}
\hline \multirow{2}{*}{ Complex } & \multicolumn{3}{|c|}{ Solubility } & \multicolumn{2}{c|}{ Acidity or alkalinity } \\
\cline { 2 - 6 } & Water & Acetone & Xylene & Acidity & Alkalinity \\
\hline$\left[\mathrm{CrCl}_{3}(\mathrm{~L})_{3}\right] \cdot 6 \mathrm{H}_{2} \mathrm{O}$ & Not soluble & Not soluble & Not soluble & 7.25 & - \\
\hline$\left[\mathrm{FeCl}_{3}(\mathrm{~L})_{3}\right] \cdot 6 \mathrm{H}_{2} \mathrm{O}$ & Not soluble & $14 \%$ & Not soluble & 4.60 & - \\
\hline$\left[\mathrm{Cu}\left(\mathrm{CH}_{3} \mathrm{COO}\right)_{2}(\mathrm{~L})_{3}\right] \cdot 2 \mathrm{H}_{2} \mathrm{O}$ & Not soluble & Not soluble & Not soluble & 7.25 & - \\
\hline
\end{tabular}

$\mathrm{L}=$ 2-methyl-quinazolinone.

Calcium carbonate possessed an ionization constant $\mathrm{pK}_{\mathrm{a}}$ higher than 3.3 (Table 6). Accordingly this carrier has slight acidic surface sites that are safe to mixed with our complexes. However talck has $\mathrm{pK}_{\mathrm{a}}$ level $>1.5$ and $<3.3$. This means that talck has acidic sites less than calcium carbonate. On the other hand both tested carriers were slightly alkaline and varied in their $\mathrm{pH}$ values. Talck showed the highest $\mathrm{pH}$ value 8.33 , while calcium carbonate possessed lower value 7.98

The tested inert varied considerably according to their bulk density. Calcium carbonate showed the highest bulk densities (loss and packed) $(0.8,1.14)$. According to the specifications of WHO (1979), the bulk density of powder after compacting (packed bulk density) should not exceed the value obtained before compacting by more than $60 \%$, both tested inert confirmed these specification. On the other hand, calcium carbonate and talck have particle size range less than 40 microns.

Table 6. Physico-chemical properties of diluents.

\begin{tabular}{|c|c|c|c|c|c|c|c|c|c|}
\hline \multirow{2}{*}{ Diluent } & \multirow{2}{*}{$\mathrm{pK}_{\mathrm{a}}$} & \multirow{2}{*}{$\begin{array}{c}\mathrm{pH} \text { at } \\
25{ }^{\circ} \mathrm{C}\end{array}$} & \multirow{2}{*}{$\begin{array}{c}\text { Alkalinity } \% \\
\text { as NaOH }\end{array}$} & \multicolumn{2}{|c|}{ Bulk density } & \multicolumn{4}{|c|}{ Screening analysis less than } \\
\cline { 5 - 11 } & & & $\begin{array}{c}\text { Before } \\
\text { comp. }\end{array}$ & $\begin{array}{c}\text { After } \\
\text { comp. }\end{array}$ & 53 & 40 & 30 & 96 \\
\hline Calcium-carbonate & $>3.3$ & 7.98 & 0.013 & 0.80 & 1.14 & 100 & 100 & 99 & 96 \\
\hline Talck powder & $>1.5<3.3$ & 8.33 & 0.0057 & 0.36 & 0.41 & 100 & 100 & 100 & 100 \\
\hline
\end{tabular}

\section{CONCLUSION}

The new reaction of some transition metals $\mathrm{Cr}(\mathrm{III}), \mathrm{Fe}(\mathrm{III})$ and $\mathrm{Cu}$ (II) with 2-methylquinazolinone (L) has been studied. The results of the elemental analysis, molar conductivity, magnetic moment, infrared spectra and thermogravimetric analysis deduced the formation of 1:3 metal/ligand complexes in all cases. Antifungal studies were carried out against several species. The results showed significant increase in antifungal activity of some metal complexes as compared with uncomplexed ligand.

\section{REFERENCES}

1. Baket, E.A.; Smith, I M. Ann. App. Biol. 1977, 87, 73.

2. Counture, R.M; Routley, D.G.; Dunn, G.M. Physiol. Mol. Plant Pathol. 1971, 1, 515.

3. Friebe, A.; Vilich, V.; Hennig, L.; Kluge, M.; Sticker, D. Appl. Environ. Microbial. 1998, 64, 2386.

4. Richardson, M.D.; Bacon, C.W. Mycologia 1995, 87, 510. 
5. Yue, Q.;.Bacon, C.W.W.; Richardson, M.D. Phytochemistry 1998, 48, 451.

6. Walfe, J.F.; Rathman, T.L.; Sleevi, M.C.; Campbell, J.A.; Greenwood, T.D. J. Med. Chem. 1990, 33, 161.

7. Padia, J.K.; Field, M.; Hinton, J.; Meecham, K.; Pablo, J.; Pinnock, R.; Roth, B.D.; Singh, L.; Suman-Chauhan, N.; Trivedi, B.K.; Webdale, L. J. Med. Chem. 1998, 41, 1042.

8. Xia, Y.; Yang, Z.Y.; Hour, M.J.; Kuo, S.C.; Xia, P.; Bastow, K.F.; Nakanishi, Y.; Nampoothiri, P.; Hackl, T.; Hamel, E.; Lee, K.H. Bioorg. Med. Chem. Lett. 2001, 11, 1193.

9. Kenichi, O.; Yoshihisa, Y.; Toyonari, O.; Toru, I.; Yoshio, I. J. Med. Chem. 1985, 28, 568.

10. Buchanan, J.G.; Sable, H.Z. in Selective Organic Transformations; Thyagarajan B. (Ed.), 2nd ed., Wiley-Interscience: New York; 1972; p 95.

11. Segarra,V.; Crespo, M.I.; Pujol, F.; Belata, J.; Domenech, T.; Miralpeix, M.; Palacios, J.M.; Castro, A.; Martinez, A. Bioorg. Med. Chem. Lett. 1998, 8, 505.

12. Akazom, M.; Yamamoto, J.; Kondo, T.; Watanabe, Y. J. Organomet. Chem. 1995, 494, 229.

13. Gupta, B.M.; Agraval, U.; Khan, S. K. Indian J. Exp. Biol. 1963, 7, 61.

14. Bouillant, M. L.; Farre-Bonvin, J.; Ricci, P. Tetrahedron Lett. 1983, 24, 51.

15. Mayama, S.; Tani, T.; Mastura, Y. J. Am. Oil Chem. Soc. 1981, 5, 697.

16. Bulluci, C.; Gualtieri, F.; Chiarini, A. Eur. J. Med Chem. 1987, 22, 473.

17. Aly, M.M.; Mohamed, Y.A.; El-Bayouki, K.A.M.; Basyouni, W.M.; Abbas, S.Y. Europ. J. of Med. Chem. 2010, 45, 3365.

18. Rashad, A.E.; Shamroukh, A.H.; El-Hashash, M.A.; El-Farargy, A.F.; Yousif, N.M.; Salama M.A.; Mostafa, A.; El-Shahat, M. J. Heterocyclic. Chem. 2012, 49, 1130.

19. Argarego, W.L.F.; Purrin, D.D. Purification of Laboratory Chemicals, 4th ed., Butterworth: Oxford; 1997.

20. El-Farargy, A.F.; Hamad, M.M.; Said, S.A.; Sayed, Ahmed, A.F.; El-Gendy, G.M.; Pak. J. Sci. 1992, 35, 19; Kim-Dong, H. J. Heterocycl. Chem. 1975, 6, 1165.

21. Albertin, G.; Bordignon, E.; Orio, A.A. Inorg. Chem. 1975, 14, 1411.

22. Fallik, E.; Klein, J.; Grinberg, S.; Lomaniee, C.E.; Lurie, S.; Lalazar, A 1993, 77, 985.

23. Dutta, R.L.; Syamal, A. Elements of Magnato Chemistry, S. Chand and Company Ltd.: New Delhi; 1982.

24. David, N. Complexes and First-Row Transition Elements, Macmillan Press: London; 1974; p 104.

25. Castillo-Blum, S.E.; Barba-Behrens, N. Coord. Chem. Rev. 2000, 3, 196.

26. Nakamoto, K. Infrared and Raman Spectra of Inorganic and Coordination Compounds, 4th ed., Wiley: New York; 1986; p 230.

27. Sadeek, S.A.; El-Farargy, A.F.; El-Kady, A.M.A.; Genidy, G.; Abd El-Lattif, N.S. Latvian J. Chem. 2012, 2, 66.

28. Almadfa, H.; Said, A.A.; Nour, E.M. Bull. Soc. Chem. Fr. 1991, 128, 137.

29. Karlin, K.D.; Zubieta, J. (Eds.) Copper Coordination Chemistry: Biochemical and Inorganic Perspectives, Adenine Press; New York; 1983; p 43.

30. Cotton, F.A.; Wilkinson, G.; Murillo, C.A.; Bochmann, M. Advanced Inorganic Chemistry, 6th ed., Wiley: New York; 1999; $p 857$.

31. Nour, E.M.; AlKority, A.M.; Sadeek, S.A.; Teleb, S.M. Synth. React. Inorg. Met. Org. Chem. 1993, 23, 39.

32. Niemeyer, H M. Phytochemistry 1988, 27, 334. 